\title{
Technology Transformation and Its Impact on Lecturer's Performance
}

\author{
S. Arifin ${ }^{1^{*}}$, M. Sukmawidjaya ${ }^{2}$ \\ ${ }^{1}$ English Graduate Program Universitas Muhammadiyah Prof. Dr. Hamka (Uhamka) Jakarta, Indonesia \\ ${ }^{2}$ Fakultas Teknik Industri Trisakti-Jakarta, Indonesia \\ e-mail: syaadiah.arifin@uhamka.ac.id,maula@trisakti.ac.id
}

\begin{abstract}
The interest to do this research is to investigate the impact of technology transformation on the lecturer's performance. The terms technical performance in this research are divided into five (5) indicators: engaging and empowering learning, and teaching with technology, leadership, accommodation (syllabus and lesson scheme), and infrastructure provided by the campus. The findings indicate that many lecturers have a lack of knowledge in technology transformation. However, all lecturers must have it for the teaching and learning process in the 21st-century. The research methods used were descriptive analysis, observations, quantitative and semi-structured qualitative research, and the questionnaires done using Google Form. There were sixty-four (64) respondents in this research. The result shows that the use of technology proves its significant impact on the lecturer's performance.
\end{abstract}

Keywords: Technology Transformation; The Impact of Lecturers' Performance; Learning Process

\section{Introduction}

Nowadays, the use of information technologies is increasingly important since it has frequently been adapted and integrated into the educational process. In an educational environment, technology has always been used to instruct the learning process. The emergence of newer forms of technologies such as computer interaction, the internet use, and social media disc interaction are actually part of educational technology.

The existence of information communication of technology (ICT) does not transform teacher practices. However, ICTs enable teachers to transform their teaching practices, given a set of enabling conditions. Teachers' pedagogical practices and reasoning influence their uses of ICT, and the nature of teacher ICT use impacts students' achievement. (CD-i) videodiscs, DVDs, and desktop have created a renewed interest in the use of supporting teaching and learning processes (Duhaney, 2000; Gerard, 2010).

The problems faced by most lecturers are usually unequal distribution of training opportunities. Frankly, many Indonesian lecturers have insufficient technology in the class. The knowledge of information technologies in the classroom, have not been used to improve the learning experience. Some lecturers use the virtual learning environment only to provide notes and submit assignments, including a comprehensive reading list of books and articles for students to read. Surprisingly, the students do not read books; in fact, they pull them apart for quotes at assignment (Graham, 2016; Sweden, 2017; Mardiana, 2018).

In the previous studies, Gerard (2010) stated that lecturers should be responsible for preparing themselves to increase their knowledge and skill in technologies. Other scholars, teaching performance with information communication technology (ICT) should be focused on the adoption of technology in learning product with the maximum impact on students' outcomes (Kayes, 2002).

Yang, Sukwadi and $\mathrm{Mu}(2010)$ suggested that the effect of work satisfaction can be evaluated by relating it to the outputs, such as (1) work satisfaction with its productivity, (2) work satisfaction and turnover, (3) work satisfaction and absence, (4) work satisfaction with

\footnotetext{
${ }^{*}$ Corresponding author.

Received 13 January 2020; Accepted 20 March 2020; Available online 31 March 2020

(C) 2020 JPI. All Rights Reserved
} 
other effects such as physical-mental health, the capability to learn a new job and work accident.

The present study attempted to describe that the lecturer's performance is viewed as a combination of a work which must be achieved by the lecturer, and how to achieve it. Performance in technology transformation is a combination of work such as using technology transform and knowledge transform, which must comply with the curriculum that the campus has given.

The purpose of the lecturers' performance is indicated with: improving the performance of lecturer by helping them to realize and use their potential role in realizing the objectives of the organization; providing the information on lecturers and managers as a basis for making decisions relating to employment. This research aims to seek the impact of technology transformation on the lecturer's performance; in particular, whether or not technology transformation can improve the lecturer's performance toward teaching and learning in the classroom based on engaging and empowering learning, teaching with technology, leadership, accommodation, and infrastructure.

\subsection{Grand Theory of Technology Transformation}

The existence of technology does not transform lecturers' practices; in fact, it enables lecturers to transform their practices and conditions. Lecturers' pedagogical practices and reasoning will influence their use of technologies, and the nature of teacher technology use impacts students' achievement (Trucano, 2005). It is suggested that introducing technology alone will not change the teaching and learning process.

Technology plays a vital role in the teaching and learning process from the dissemination of information to hosting sessions about technology that can be used to benefit in education. For example, technology provided needs to be examined, and the lecturer tries to find suitable for inclusion to the related subject (Starkings, 1996). World Wide Website, multimedia presentation tools in the teaching and learning process give some benefits to lecturers to organize their teaching in an efficient manner (Achacoso, 2003).

The purpose of performance on the lecturer's performance is followed by: improving the performance of lecturer by helping them to realize and use their potential role in realizing the objectives of the organization; providing the information on lecturers and managers as a basis for making decisions relating to employment. In particular, the use of technology transforms is divided into five categories: Engaging and Empowering Learning; Teaching with Technology; Leadership; Accommodation; Infrastructure.

\subsection{Engaging and Empowering Learning}

By using technologies as the learning approach, the research has shown that higher education institutions face significant challenges regarding the management of performance. Furthermore, the function of lecturers is to use their professional knowledge and skills to take action, which could reasonably be expected to facilitate learning for students with whom they have a learning and teaching relationship (Mapesela \& Strydom, 2004).

The challenge to use technology is beyond automation to engagement. The ability of digital technologies to facilitate connections and interactions, to generate observable data about the connections and interaction will allow institutions to identify and capitalize on efficiencies and ways to improve effectiveness, transforming on working to learn (Oblinger, 2014).

\subsection{Teaching with Technology}

The use of technology means teaching with the application of technology, which students will independently learn through the internet. They will progress, master the material and choose the pace to learn. Students will have self-discipline and find sufficient and explicit materials which will be performed immediately to get a result and track their progress (Stošić, 2015). Lecturers need to compel the reasons to change the instructional practice and to use technology that supports inquiry-based and learner-centered instruction, 
which are the content, curriculum, instruction, and the use of technology and assessment. (Burn, 2016).

\subsection{Leadership}

One of the most important characteristics of a learning organization needs to develop a joint vision, secure cooperation and provide the necessary underlying conditions for technology use in education organization (Anderson \& Dexter, 2005). Leaders should open their minds to technology and innovation by making use of new technologies themselves, such as lecturers' computers and administrators to work in shape and effectively by using technology (Cakir, 2012).

\subsection{Accommodation}

Acceleration of technological developments has changed the service environment in presenting the opportunities and challenges to serve the campus and the stakeholders. The students as the stakeholders will respond to the service from campus to introduce technologies enabling service which include the mature services of online response from the students or stakeholders and emerging the services such as mobile-based systems and complementary the use of IPad in campus (Wang \& Sparks, 2014). To be a valuable asset and an effective competitive strategy, the campus must consider the stakeholders or students need perception as a limited proportional to increase the availability of the service (Beatson, Coote, \& Rudd, 2006).

\subsection{Infrastructure}

By means of a part basic activity in education teaching and learning, technology application and computers are supported as literacy. The specified concepts and education technologies have gained functionality about preparing the teaching program and bringing up qualified individuals by applying the teaching program (Butler \& Sellbom, 2007). A formation compels to form modern teaching environments, develops environments for infrastructure and improves knowledge and abilities to technological developments for the lecturers who will be the guide to the formation of interacted participants, and productive teaching and learning process. (Department Education, 2017).

Based on the five categories of usefulness of technologies, it is indicated that to gain in engaging students' knowledge and skills in terms of synthesizing content skills, the process of teaching and learning will be sustainable and the students" ability to have selfdiscipline will grow (Molefe, 2010).

\section{Method}

This research is a quantitative research, that determine the technology transformation on the lecturers' performances based on engaging and empowering learning, teaching with technology, leadership, accommodation, and infrastructure. The subject sampling selection was applied to sixty-four (64) lecturers, which have spread out through Google form. Data collection technique regarding qualitative was collected from lecturers to be interviewed for 2-3 hours in June and July 2019. A series of works had been undertaken to collect data for the research related to the literature review. Moreover, the author developed questionnaires; Semi-structured interviews were conducted with the author.

\subsection{Material of Research}

The author aims to use quantitative research, which is to determine the technology transformation that impacts the lecturer's performance. Notably, the research tries to find the improvement of the lecturer's performance by transforming the technology and the strategies for the learning process that the lecturer serves in adapting the technology to do the demands of faculty and students. Subject sampling selection was applied to 64 lecturers taken from Google form. Data collection technique regarding qualitative was collected by semi-structured interviews with five lecturers to conduct the research. 


\subsection{Research Instrument}

The questionnaires for the research were developed and deployed for the interaction between lecturers and faculty, lecturers and staff, lecturers, and students. The technology used were: computers, laptops, Power Point, Internet, and other social media such as Facebook, Twitter. The questions were developed to measure respondents' usage of technology in implementing a learning process or interaction with staff, faculty, and technician. For this research, an extensive exploratory phase was conducted in order to ascertain important issue between users and nonuser to technology transformation. The questionnaires were divided into five dimensions, namely, the engaging and empowering learning has indicated to the lecturers' performances, teaching with technology has a relationship with the lecturers' performances, leadership has a relationship with lecturer's performance, the accommodation has an impact on the lecturer's performance, and the infrastructure influences lecturers' performance.

\subsection{Research Procedure}

Likert-scale was used in this research. The items for questionnaires were divided into five (5) dimensions of questions about technology transformation which will impact lecturer's performance. The questionnaires were used to the questions from [1] strongly disagree, [2] disagree, [3] agree, and [4] strongly agree. Respondents for this research were $100 \%(n=64)$. The interview was given to 8 lecturers regarding to the technology transformation that gived the impact to the lecturer's performance in the classroom.

\subsection{Variables and Hypothesis}

This section is a brief explanation prior to the study. An extensive exploratory phase was explained in order to accomplish the hypothesis. In the hypothesis, the study research issues are divided into 5 dimensions, such as to the engaging and empowering learning has impacted to the lecturers' performances $(\mathrm{H} 1)$, teaching with technology has relationship with the lecturer's performances $(\mathrm{H} 2)$, leadership has relationship with lecturer's performance $(\mathrm{H} 3)$, the accommodation has an impact on the lecturer's performance $(\mathrm{H} 4)$, and the infrastructure influences to lecturers' performance $(\mathrm{H} 5)$.

\section{Result and Discussion}

From the questionnaires, it was found that the frequencies and percent values of the lecturer's performance for teaching and learning were analyzed, and from the questionnaires about technology transformation has an impact on the lecturer's performance. The research indicates that the value of research using SPSS vs. 20.

\begin{tabular}{|c|c|c|c|c|c|c|c|c|c|}
\hline \multirow[t]{2}{*}{ Indicators } & \multicolumn{8}{|c|}{ Correlation } & \multirow[t]{2}{*}{$\alpha$} \\
\hline & Q1 & Q2 & Q3 & Q4 & Q5 & Q6 & Q7 & Q8 & \\
\hline Indicator 1 & 0.858 & 0.866 & 0.944 & 0.788 & -0.421 & 0.664 & 0.881 & 0.897 & 0.766 \\
\hline Indicator 2 & 0.665 & 0.745 & 0.699 & 0.677 & 0.299 & -0.438 & 0.683 & 0.315 & 0.545 \\
\hline Indicator 3 & 0.882 & 0.877 & 0.650 & 0.861 & 0.813 & 0.821 & 0.422 & & 0.780 \\
\hline Indicator 4 & 0.675 & 0.511 & 0.540 & 0.597 & 0.496 & 0.415 & & & 0.780 \\
\hline Indicator 5 & 0.331 & 0.785 & 0.708 & 0.775 & 0.768 & 0.407 & 0.437 & & 0.708 \\
\hline
\end{tabular}

From the data, it is shown that the reliability Cronbach's Alpha is 0.766 , and from the variable of engaging and empowering learning has shown that there is an impact on the lecturer's performance. Only Q5 has a negative value because the question in the questionnaires is negative or different. Thus the impact of engaging and empowering learning on the lecturer is acceptable. Technology would engage, empower lecturers to a new level of learning which is emerging technology tools and services to help lecturers develop the skills that they need for teaching in the 21st-century learning process (Mardiana, 2018). It is believed that by bringing the Internet into every classroom, would bring the world and a majority of relevant precious resources for learning, and not only the promise of increasing efficiencies and productivity but also it could be a catalyst for defining a new 
approach to teaching and learning as a new knowledge-based (Tomorrow, 2011). Lecturers transform the technologies and have the ability to use the knowledge and technologies to manage teaching and learning in the classroom (Granberg, 2000). With technology, the lecturers will handle the learning process without any problem, such as the Internet, social media, the use of Power Point that are needed for teaching (Ramey, 2017).

\subsection{Variable of the relationship between teaching with technology and the lecturer's performance}

Research data shown that with reliability Cronbach's Alpha is 0.670 , and from each question of questionnaires has the relationship between teaching with technology and the lecturer's performance. This data is shown that the value of beta tells how much the predicted value (Q6) changes when the corresponding predictor is increasing and holding all other predictors constant. Question 6 is a negative question that can be the predictor. Therefore, this data is shown that there is a relationship between teaching with technology and the lecturer's performance.

Lecturers transform the technologies and have the ability to use the knowledge and technologies to manage teaching and learning in the classroom (Granberg, 2000). Right now, technologies used are the essential tool to teach in the class, which provides the use of the Internet, social media, the use of PowerPoint that are needed for teaching ( Ramey, 2017). Shyamlee et., al (2012) stated that multimedia of technology emerges the development of technology and the application to teaching, featuring audio, visual effect comes into full play in teaching, and it is a set of favorable platforms for reform and exploration on teaching with technology. It means that lecturers who can use technology can explore the teaching and learning, and the teaching will impact on students' achievements. From the definition of technologies in the learning process, it can be seen that the connection between both of them. Lecturers who can use technologies will have pleasant conditions in teaching, and it means that technologies are established in lecturers' ability.

This data research is shown with reliability Alpha Cronbach 0.545 , which indicates that the questions on questionnaires are reliable, and it can be used for data of the relationship between teaching with technology and the lecturer's performance.

\subsection{Variable of Leadership has relationship with lecturer's performance $(H 3)$}

Data above, it is shown that the reliability (a) 0.780 , which stated that the questions on questionnaires are reliable and it can be used for data of the relationship between leadership and the lecturer's performance. The relationship between leadership and the lecturer's performance is indicated that there is a relationship between leadership and the lecturer's performance. Leadership takes a role in the lecturer's performance to teach in the classroom. Each of the items of Q1, Q2, Q3, Q4, Q5, and Q6 has a strong relationship. Q7 has a weak relationship. The questions for Q7 are about personal questions which are related to the technology and learning process. Not all of the lecturers use technology in the classroom even though they think it is essential. Moreover, not all of the lecturers and students can adopt it easily.

Leadership is the primary role in educational technology, which is to integrate the technology into the classroom, and the lecturer needs to examine the skills required to be a leader in any situation (Courville, 2011). As a unique position as a leader in educational technology, it requires a focus on two sets of skills: organizational leadership skills and skills related to the use of technology. The framework for this research is to view the required skills of learning. Leaders should open their minds to technology and innovation by making use of new technologies such as computer use, administrator to work in shape and effective technology use (Senge, 2010). Taking full advantage of technology to transform learning requires strong leadership capable of creating a shared vision of which all members of the community feel apart. Leaders who believe they can delegate the articulation of a vision for how technology can support their learning goals to a chief information officer or chief technology officer fundamentally misunderstand how technology can impact the teaching ( 
Adams, 2016). So, the conclusion for this variable is that there is a relationship between leadership and the lecturer's performance.

\subsection{Variable the accommodation has an impact to the lecturer's performance}

In this research, data is taken which reliability is 0.708 , which is a strong impact of the accommodation on the lecturer's performance. From the data above, the relationship between accommodation and lecturer's performance has an impact even though the relationship is not strong enough. But there is an impact on the lecturer's performance in the classroom. The strong relationship which gives an impact to the lecturer's performance is Q1; it is whether the lecturers have difficulty in accessing technologies in the classroom. Most answers are no difficulty. All of the questions beside Q1 about the accommodation, and it is very often that the lecturers provide themselves to bring in the classroom, such as the internet, computers, infocus projector, light, plug, and else. Most of the infrastructures in campuses have not been adequate, and all of these would not be able to discourage the lecturer's performance in using technology in the classroom. Another accommodation is about the lecturer's incentives, campuses provide training, but it is only for the permanent lecturers.

Accommodation is the most fundamental act and art of teaching. It is not the exception we sometimes make despite learning, but rather the adaptations we continually make to promote learning. Accommodation often has a more narrow definition in the academy, appearing notably in the syllabus (Womack, 2017). This research takes up the academic accommodation to discuss the contemporary theories of teaching which is accommodated through the accessibility of the learning process. Technology development will help the acceleration of learning by having the syllabus, and the students and stakeholders will use the accommodation as a service online. The response from students and stakeholders will help the lecturers to understand whether the learning process is run ( Stack, 2008). The conclusion is that there is an impact on the relationship between accommodation and the lecturer's performance.

\subsection{Variables of The Influence of Infrastructure towards Lecturer's Performance}

Data shows that reliability of the influence of infrastructure towards lectureperformance is 0.743 , which is reliable and valid. It is stated that there is an influence of infrastructure on the lecturer's performance. In Q1, the question is about the lecturer's understanding of using technologies in the classroom, and campuses support the technologies. Some lecturers mentioned that they have never supported the technologies in the classroom; in fact, they have had it and use it for teaching. Q6 and Q7 are about the knowledge of electronics provided by campuses and the importance of using technologies. Some lecturers stated that they have a limited amount of knowledge to use technologies, especially the new technologies such as the Internet, social media, and they have also thought that there is not necessary to use technologies in the classroom. For these factors, it may be some other researchers would like to take the research about the use of technologies in the classroom. Moreover, from this test, the influence of infrastructure on the lecturer's performance is tested and valid.

Campus facilities, including infrastructure, are the plan that campus provides for lectures, staff, technicians, administrators lab tech, cleaning service. Infrastructure concept development for the campus is the process iterative and inclusive of campus members' input, all plans that are subject to endorsement and advice, investment of time, and money to achieve the goal (Craven, 2014). To gain the lecturer's performance and function as optimal as possible, it needs excellent facilities such as infrastructure, room, technologies. (Trisnantoro, 2016). The infrastructure influences the academic atmosphere as conducive as possible, and at the same time, it will impact lecturer's performance (Stielow, 2012). In this research, technology transformation is variable; the influence of infrastructure towards lecturer's performance is tested. 
All variables have been tested, and the result of the research from variable 1 through variable five is shown in table 2 .

Table 2. The Relationship and the Influence of Technologies Transformation towards Lecturer's Performance

\begin{tabular}{cccc}
\hline Variables & Sig. (2-tailed) & Std. Coeff. & Correlation \\
\hline Q1 & 0.000 & 0.357 & 0.775 \\
Q2 & 0.000 & 0.282 & 0.801 \\
Q3 & 0.000 & 0.314 & 0.650 \\
Q4 & 0.000 & 0.254 & 0.662 \\
Q5 & 0.000 & 0.192 & 0.653 \\
Total & 0.000 & - & 1.000 \\
\hline
\end{tabular}

Source: Research Process

The reliability of the relationship and influence of technology transformation towards the lecturer's performance is 0.778 . It is indicated that the relationship and influence of technology transformation towards the lecturer's performance is reliable and valid. From the data, each category of the question in questionnaires has stated that there are influences between one variable to other variables. The strongest relationship is in Q2 $(0.801$; std. coeff. 0.282 and sign.2-tailed 0.000 ), the teaching by using technologies. All the lecturers seem to agree that technologies are used in the classroom, and the lecturer should transform the learning by technologies. Technologies have contributed to teaching and learning and will make the teaching easier and run well. Q1 (0.775; std.coeff. 0.357 and sign. 2-tailed 0.000 is engaging and empowering teaching and learning, which gives the lectures strength to teach in the classroom because the lecturer use technologies such as PowerPoint, Excel, window doc, the Internet, and social media. The teaching will be on the right track, and students will focus on learning. Furthermore, Q4 and Q5 are in the third and the fourth level, because they are a tangible asset which campus provides. Moreover, there are not many campuses that provide accommodation and infrastructure, even though in the 21 st-century teaching and learning process are a must. Q3 is about leadership; in fact, all of the lecturers need to have leadership in his or her personality.

The proliferation of emerging technologies has led to new education paradigms, including technologies transformation to deliver supplemented material. Technology plays an essential role in the teaching and learning process, which is provided to be examined, and the lecturer needs to find a suitable subject to teach (Ali, 2015). Engaging and empowering technology are basic tools and services to help lecturers to sharpen the competency skill for the learning process (Mardiana, 2018). The knowledge of technology is the guidance that technology cannot be ignored in teaching. Moreover, the lecturers can transform the technologies based on their ability to handle the learning process without any problem such as the Internet, social media, and PowerPoint, Excel, Microsoft word for teaching ( Ramey, 2017). By using many features in technologies, students will have a more natural way to follow the learning in the subject (Rink, 2016). With the analysis from table 2, which is Q2 $(0.745)$ lecturers understand and know of technologies transform; it is stated that lecturers know how to use technologies and know how to transform technology, and this is engaging and empowering the lecturer's performance. Lectures are ready for teaching with all the knowledge in the head and skill with their own (Long, Ibrahim, \& Kowang, 2014). Leadership is understood as dynamic processes that can influence others. The relationship between leadership and the lecturer's performance is tied as an exercise to achieve a goal in a particular situation. A leader needs authority to compromise and to set up the legitimate power, authority by law or regulation, and entities the one with the issue binding and to use their knowledge to pursue students in order to have a better attitude and knowledge (Mardiana, 2018). By having leadership, the lecturer can manage their performance in the classroom. In terms of specific variables of the lecturer's competencies, interaction often appears as a defining characteristic of teaching and learning experiences. The 
accommodation for lecturers is measured in teaching and preparing the teaching, giving assessments to the students, and interacting with students, staff, technicians, campus officers, and others (Banerjee \& Brincknerhoff, 2002). Lecturers must have tasks in the process of teaching in performing the course contents, accomplishments feedback, stimulate students' motivation to process and reflect on the content and assist them to engage in learning activities. Moreover, they must perform a variety of tasks in the process of teaching, e.g., provide a structure of the course contents, give feedback of accomplishments, stimulate students' motivation to process and reflect on the content, and assist them to engage in learning activities (Brophy, 2001).

Right now, infrastructure on campus goes to the same systems as the learning process. Infrastructure gives the capacity of how well the campuses adjust to the $21 \mathrm{st}-$ century learning process (Craven, 2014). A technology that is a part of the learning process is provided by the infrastructure campus that the lecturers should understand how to use it. In each class and room in campus, the Internet, as one of the infrastructures, should have technologies, and the lectures are more comfortable to transform the technologies to the students in the learning process (Burn, 2016). Campus management will be the structure with online capacity, and each member of the campus officer should understand the infrastructures and knowledge of the infrastructure management and needs to be evaluated in duration depending on the campus (Butler \& Sellbom, 2007).

With all of the variables that this research has done, the technology transformation towards the lecturer's performance can improve the learning process and will have a profitable campus to promote for teaching and learning in the 21 st learning process.

\section{Conclusion}

Technology transformation is one of the most useful tools that the lecturers need in the classroom. Lecturers' knowledge and skills need to be sharpened in order to have excellent teaching performance besides the curriculum of campus and infrastructure that all campuses provide. The relationship between engagement and empowering of learning with the lecturer's performance brings the plethora of learning increasingly and efficiently productive. A strong lecturer's knowledge and skills of the use of technologies will manage the learning process run smoothly, and students will be enthusiastic in learning.

The ability to use technology can explore teaching and learning. Furthermore, it will impact on the students' achievement. The relationship between both of them will give a good impact on the students' achievements to learn well. Moreover, lecturers should have leadership skills and the skills related to the use of technology. The framework of leadership is required to innovate knowledge and skills. The skills include the capability of creating a vision of all members who feel better as a part of supporting the learning goals.

Accommodation means that lecturers provide the syllabus, lesson scheme, and teaching material. Lecturers can discuss the contemporaries' theories of teaching, which is accessible to the learning process. Technology development helps the lecturers to accelerate the learning online, and the lecturers will respond from students, members of the campus, and stakeholders about the learning process.

The facilities of infrastructure that the campus provides for lecturers, staff, technicians, administrators, lab Techs are the concept of development to have a better learning process for the students. To gain the lecturer's performance and function as optimal as possible is when all members of the campus can use the infrastructure. The learning atmosphere gives a good education process, and it is an excellent opportunity for lecturers to have technology transformation for the learning process.

Teaching will be on the right track when the lecturer can transform the technology well because, with all of the indicators given above, the education will be ready for the 21 stcentury learning process. 


\section{References}

Achacoso, M. (2003). Evaluating Technology and Instruction: Literature Review and Recommendations. Austin, TX: he University of Texas at Austin Division of Instructional Innovation and Assessment.

Adams, B. (2016). Leadership. Retrieved from Office of Education Technology, Department of Education Gov of US: https://tech.ed.gov/netp/leadership/

Ali, A. (2015). Performance Lecturer's Competence as the Quality Assurance. The International Journal of Social Sciences, 30 (1), 30-45.

Anderson, R. E., \& Dexter, S. (2005). School technology leadeshipAn emprical investigation to prevelance and effect. Educational Administration Quarterly, 41 (1), 49-82.

Banerjee, M., \& Brincknerhoff, L. C. (2002). Assessing Student Performance in Distance Education Courses: Implications for Testing Accommodations for Students with Learning Disabilities. Assessment for Effective Intervention, 27 (3), 25-35.

Beatson, A., Coote, L. V., \& Rudd, J. M. (2006). Dermining consumer and commitment through self service technology and personal service usage. Journal of Marketing Management, 22 (7), 853-882.

Brophy, J. (2001). Generic Aspects of Effective Teaching. In M. C. Wang, \& H. J. Walberg (Eds), Tomorrow's Teacher's . McCutchan Publishing Company.

Burn, M. (2016). Deep Learning with Simple Technologies. Tbilisi, Georgia: Education Development Center.

Butler, D. L., \& Sellbom, M. (2007). Barriers to Adopting Technology. Educause Quarterly 4 (2), 22-28.

Cakir, R. (2012). Technology Integration and Technology Leadership in Schools as Learning Organizations. The Turkish Online Journal of Educational Technology, 11 (4) , 273282.

Courville, K. (2011). The 2011 Louisiana Computer Using Educator's Conference. Retrieved from Educational Technology: Effective Leadership and Current Initiatives : https://files.eric.ed.gov/fulltext/ED527339.pdf

Craven, G. (2014, June 19). Campus Infrastructure Development Procedure. Retrieved from Australian Catholic University: file://C:/Users/Lenovo/Desktop/Journal\%20Harisa/Technologies\%20Transformation/C ampus_Infrastructure_Development_Procedure.pdf

Department Education, U. (2017). Building Technology Infrastructure for Learning. Washington, DC: US Department of Education.

Duhaney, D. C. (2000). Technology and Educational Process: Transforming Activities. International of Instructional Media, 27 (1), 67-72.

Erişti, S. D., \& Kurt, A. A. (2012). Teachers' Views about Effective Use of Technology in Classrooms . Turkish Online Journal of Qualitative Inquiry, 3 (2), 30-41.

Gérard, G. (2010). The constellation of being: Reading of heidegger's identity and difference [La constellation de l'être: Lecture d'Identité et. Studia Phaenomenologica, 10 (1), 313332.

Graham, D. (2016). Paid With Compliment, Not Cash. Jakarta, DKI, Indonesia.

Granberg, E. M. (2000). How Technology Enhances Teaching and Learning. Nashville, TN, US.

Kayes, D. C. (2002). Experiential learning and its critics: Preserving the role of experience in management education learning and education. Academy of Management Learning and Education Vo. 1 No. 2, 137-149.

Long , C. S., Ibrahim, Z., \& Kowang, T. O. (2014). An Analysis on the Relationship between Lecturers' Competencies and Students' Satisfaction. International Education Studies; 7 (1), 37-46.

Oblinger, D. (2014). Designed to Engage. Oakland, San Francisco, California.

Ramey, K. (2017). The Use of Technology - In Education and Teaching Process . US.

Senge, P. (2010). Pedagog Infed. Retrieved from Learning Organization: https://api.ag.purdue.edu/api/depotws/File.ashx?t=f\&i=11736 
Stack, E. (2008). ICT in School: Inspectorat Evaluation Studies. Dublin: Evaluation Support and Research Unit, Inspectorat Department of Education and Science.

Starkings, S. (1996). How Technological Introduction Changes The Teaching of Statistics and Probability at The College Level. Proceedings of the 1996 IASE Round Table Conference (pp. 243-254). Granada, Spain: International Statistical Institute, Voorburg, The Netherlands.

Stielow, F. (2012). Technology Transforming Education: 4 Real-World Models of Success. Arlington, VA: Rosetta Stone of Education.

Trisnantoro, L. (2016). Standar minimal fasilitas infrastruktur untuk pemimpin struktural universitas. Retrieved from Magister Manajemen Pendidikan Tinggi Sekolah Pascasarjana Universitas Gajah Mada: http://helmmmpt.pasca.ugm.ac.id/beranda/rubrik2/2-3-5-tema-3-isu-3-standar-minimal-fasilitasinfrastruktur-untuk-pemimpin-struktural-universitas

Womack, A.-M. (2017). Teaching Is Accommodation: Universally Designing Composition Classrooms and Syllabi. New Orleans, LA: National Council of Teachers of English.

Mapesela, M. L., \& Strydom, F. (2004). Performance Management of Academic Staff in South African Higher Education System. OECD Conference on Trends in Management of Human Resources in Higher Education. Bloemfontein: University of Free State.

Mardiana, H. (2018). Lecturer's Attitude towards Advance Technology and Its Impact to the Learning Process: Case study in Tangerang City Campuses. Journal of Educational Science and Technology, 4 (1), 12-25.

Molefe, G. N. (2010). Performance measurement dimensions for lecturers at selected universities: An international perspective. SA Journal of Human Resource Management, 8 (1), 1-13.

Rink, T. (2016). 10 Ways to Empower Your Students in the Classroom. Retrieved from Mimio Educator: http://blog.mimio.com/10-ways-to-empower-your-students-in-theclassroom

Stošić, L. (2015). The Importance of Educational Technology in Teaching. International Journal of Cognitive Research in Science, Engineering and Education, 3 (1), 111-114.

Sweden, T. (2017). The Guardian - International Edition. Retrieved from Tech skills are seriously lacking in universities - take it from the IT guy: https://www.theguardian.com/higher-education-network/2017/may/26/tech-skills-areseriously-lacking-in-universities-take-it-from-the-it-guy

Tomorrow, P. (2011). The New 3 E's of Education: Enable, Engage and Empower. Irvine, CA: National Research Project.

Trucano, M. (2005). InfoDev- Supporting By World Bank. Retrieved from Teachers, Teaching and ICTs - A Knowledge Map on Information \& Communication Technologies in Education: http://www.infodev.org/articles/teachers-teaching-and-icts

Wang , Y., \& Sparks, B. (2014). Technology-enabled services: Importance and role of technology readiness. Tourism Analysis, 19 (1), 19-33.

ADDIN Mendeley Bibliography CSL_BIBLIOGRAPHY Yang, C., Sukwadi, R. and Mu, P. (2010) 'Integrating Kano Model into Customer-Oriented Reputation Model in Higher Education'. 